\title{
Ecumenismo espiritual e renovação carismática católica em vista de maior diálogo ecumênico
}

Orientadora: Prof ${ }^{a}$. Maria Teresa de Freitas Cardoso

Pesquisadora: Maria Lucia Leme Franco

Fonte: $\mathrm{CNPq}$

Introdução

O movimento ecumênico busca a unidade dos cristãos. A Igreja Católica entrou nesse movimento e veio dando passos nesse movimento com os outros cristãos. Ela teve uma abertura maior para o ecumenismo com o Concílio Vaticano II. O Decreto Unitatis Redintegratio (UR), do concílio Vaticano II, enfatizou o desejo de unidade de Jesus e mostrou a importância do movimento ecumênico. Esse decreto falou nas diversas formas de realizar o ecumenismo. O papa João Paulo II escreveu a encíclica Ut Unum sint (UUS) sobre o ecumenismo e aprofundou o que deve ser o ecumenismo espiritual.

No ecumenismo espiritual é valorizada a oração. Esta pesquisa pretende entender o ecumenismo espiritual e ver se é possível acontecer na Renovação Carismática Católica (RCC), que tem grupos de oração. A pesquisa investiga o movimento ENCRISTUS (Encontro de Cristãos para a Unidade e a Santidade), que tem pessoas atuantes da RCC. O ENCRISTUS promove oração comum entre pessoas católicas e pentecostais. $\mathrm{O}$ ecumenismo espiritual no movimento ENCRISTUS e na RCC pode facilitar o diálogo ecumênico entre católicos e pentecostais clássicos.

\section{Objetivos}

A pesquisa tem como objetivo principal tratar do ecumenismo espiritual. A pesquisa tem como objetivos especiais, entender: 1) o que é movimento ecumênico; 2) os modos de fazer o ecumenismo; 3) o que é ecumenismo espiritual; 3) se o ecumenismo espiritual pode acontecer na Renovação Carismática Católica; 4) o ecumenismo espiritual de ENCRISTUS. 